\title{
Second-generation nitazoxanide derivatives: thiazolides are effective inhibitors of the influenza A virus
}

Andrew V Stachulski*,1, M Gabriella Santoro², Sara Piacentini², Giuseppe Belardo ${ }^{2}$, Simone La Frazia², Chandrakala Pidathala1, Eleanor C Row ${ }^{3,4}$, Neil G Berry', Mazhar lqbal ${ }^{3,5}$, Sarah A Allman ${ }^{6,7}$, J Edward Semple ${ }^{8,9}$, Brian M Eklov ${ }^{10}$, Paul M O'Neill ${ }^{1}$ \& Jean-Francois Rossignol ${ }^{11,12}$

${ }^{1}$ Robert Robinson Laboratories, Department of Chemistry, University of Liverpool, Liverpool, L69 7ZD, UK

${ }^{2}$ Department of Biology, University of Rome Tor Vergata, 00133 Rome, Italy

${ }^{3}$ At time of writing: Robert Robinson Laboratories, Department of Chemistry, University of Liverpool, Liverpool, L69 7ZD, UK

${ }^{4}$ ARCINOVA, Taylor Drive, Alnwick, Northumberland, NE 66 2DH, UK

${ }^{5}$ Health Biotechnology Division, National Institute for Biotechnology \& Genetic Engineering (NIBGE), Faisalabad, Pakistan

${ }^{6}$ Department of Life, Health \& Chemical Sciences, The Open University, Walton Hall, Milton Keynes, MK7 6AA UK

${ }^{7}$ At time of writing: Reading School of Pharmacy, Whiteknights, Reading, RG6 6AP, UK

${ }^{8}$ Rapafusyn Pharmaceuticals, 800 W. Baltimore St., Suite 406, Baltimore, MD 21201, USA

${ }^{9}$ At time of writing: Romark Laboratories, LC, Tampa, FL33607, USA

${ }^{10}$ Kalexsyn, 4502 Campus Drive, Kalamazoo, MI 49008, USA

${ }^{11}$ Romark Laboratories, LC, Tampa, FL 33607, USA

${ }^{12}$ Division of Infectious Diseases \& International Medicine, Department of Medicine, University of South Florida College of Medicine, 12901 Bruce B Downs Blvd, Tampa, FL 33612, USA

*Author for correspondence: stachuls@liv.ac.uk

Aim: The only small molecule drugs currently available for treatment of influenza A virus (IAV) are M2 ion channel blockers and sialidase inhibitors. The prototype thiazolide, nitazoxanide, has successfully completed Phase III clinical trials against acute uncomplicated influenza.Results: We report the activity of seventeen thiazolide analogs against A/PuertoRico/8/1934(H1N1), a laboratory-adapted strain of the $\mathrm{H} 1 \mathrm{~N} 1$ subtype of IAV, in a cell culture-based assay. A total of eight analogs showed $\mathrm{IC}_{50} \mathrm{~S}$ in the range of 0.14-5.0 $\mu \mathrm{M}$. Additionally a quantitative structure-property relationship study showed high correlation between experimental and predicted activity based on a molecular descriptor set. Conclusion: A range of thiazolides show useful activity against an H1N1 strain of IAV. Further evaluation of these molecules as potential new small molecule therapies is justified.

\section{Graphical abstract:}

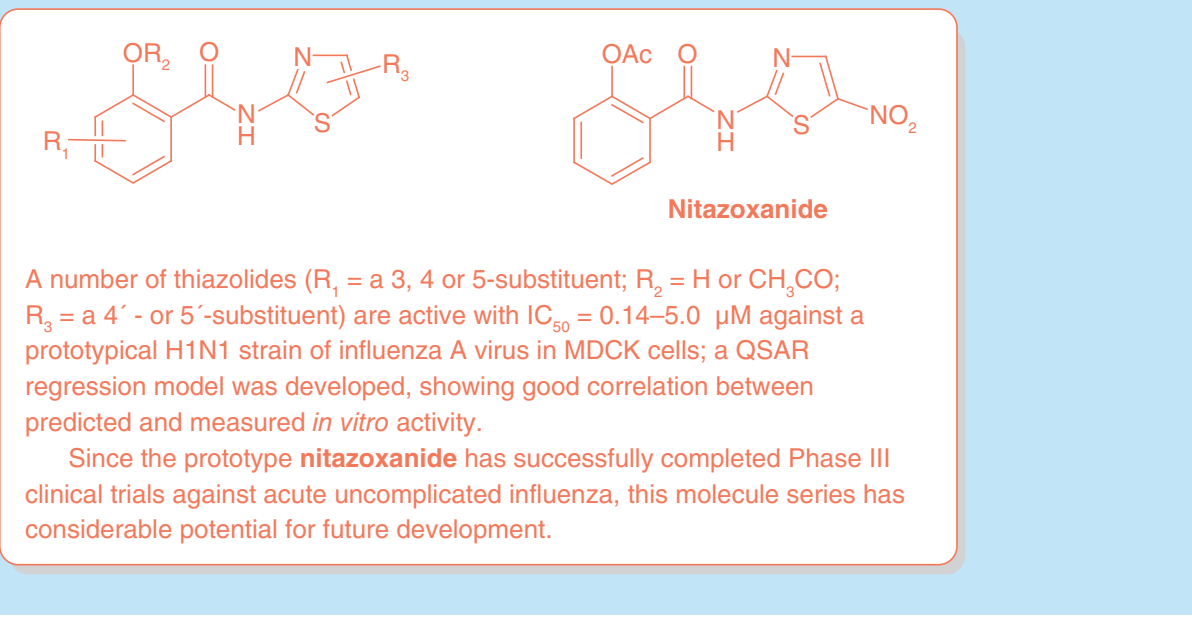


First draft submitted: 20 September 2017; Accepted for publication: 20 December 2017; Published online: 9 April 2018

Keywords: antiviral drugs • computational chemistry • drug discovery • molecular modeling

Nitazoxanide 1, Figure 1, the first of the thiazolides, and tizoxanide 2, its first circulating active metabolite, are effective in cell culture assays and in clinical trials for the treatment of influenza A and B [1-3]. Nitazoxanide was originally licensed in the USA and in many countries of the world as an antiprotozoal agent and more importantly it is the only licensed drug for the treatment of the emerging apicomplexan protozoa, Cryptosporidium parvum [4]. Its antiviral activity was first reported against the hepatitis B and C viruses [5], later against the influenza A and B viruses [2] and finally against rotavirus [6]. It is being re-purposed in the USA as a broad-spectrum antiviral agent in the treatment of viral respiratory infections. Nitazoxanide and tizoxanide are effective against a broad range of DNA and RNA viruses in cell culture assays [5], and nitazoxanide was effective in clinical trials in the treatment of rotavirus and norovirus [7] and in combination with pegylated interferon with and without ribavirin in the treatment of chronic hepatitis $\mathrm{C}[8,9]$.

The thiazolides [2-hydroxyaroyl- $N$-(thiazol-2-yl)-amides] are a family of biologically active salicylamides of 2aminothiazoles related to nitazoxanide $\mathbf{1}[10,11]$. We have disclosed the broad-spectrum antiviral activity of the thiazolides, typified by the prototype nitazoxanide $\mathbf{1}$ (Scheme 1) and described the structure-activity relationships of a wide range of thiazolides against hepatitis $B$ and $C$ viruses in particular $[12,13]$. In the case of influenza $A$ virus (IAV), we have shown that a few thiazolide analogs such as 3, 4 and 5 (Scheme 1), were also active in vitro against an $\mathrm{H} 1 \mathrm{~N} 1$ subtype and that a novel mechanism of action was involved [2].

We now present a full account of the in vitro structure-activity relationship (SAR) properties of a set of $4^{\prime}$ and $5^{\prime}$-substituted thiazolides, some of them more active than compounds $\mathbf{3} \mathbf{- 5}$, against the H1N1 strain of IAV, together with a quantitative structure-activity relationship (QSAR) analysis of the results. Recently we reported the synthesis and preclinical evaluation of new thiazolide prodrugs 6, 7 [14], Figure 2, which show greatly improved oral bioavailability compared with their parent thiazolides $\mathbf{1}$ and $\mathbf{3}$ and have good safety profiles; these compounds are also active in the in vitro study as we discuss herein.

\section{Materials \& methods/experimental Chemistry}

Organic extracts were washed finally with saturated brine, then dried over anhydrous $\mathrm{Na}_{2} \mathrm{SO}_{4}$ followed by rotary evaporation at $<30^{\circ} \mathrm{C}$. Analytical thin-layer chromatography was performed using Merck Kieselgel 60 F 254 silica plates (Merck KGaA, Darmstadt, Germany) with UV detection; preparative column chromatography was performed using silica gel, pore size 60^, particle size 40-63 micrometre (Sigma-Aldrich Co., MI, USA). Unless otherwise stated, ${ }^{1} \mathrm{H}$ and ${ }^{13} \mathrm{C}$ NMR spectra were recorded for $\mathrm{CDCl}_{3}$ solutions, containing tetramethylsilane as internal standard, using a Bruker $400 \mathrm{MHz}\left(100 \mathrm{MHz}\right.$ for $\left.{ }^{13} \mathrm{C}\right)$ instrument (Bruker UK Ltd, Coventry, UK). Avance III HD $400 \mathrm{MHz}$ spectrometer equipped with a multinuclear 5-mm BBFO probe was used. $1 \mathrm{H}$ spectra (at 400.13 $\mathrm{MHz}$ ) and $13 \mathrm{C}(1 \mathrm{H})$ spectra (at $100.61 \mathrm{Mhz}$ ) were acquired at ambient temperature using standard parameters set; solvent resonances were used for referencing purpose. Low- and high-resolution mass spectra were obtained by direct injection of sample solutions into a Micromass LCT mass spectrometer operated in the electrospray mode, by +ve or -ve ion as indicated (Micromass LCT Waters Micromass UK Ltd, Manchester, UK). CI mass spectra $\left(\mathrm{NH}_{3}\right.$ carrier) were obtained on a Fisons Instruments Trio 1000. HPLC analysis was performed using an Agilent 1100 system, eluting with a variable percentage of $\mathrm{MeCN}$ in water containing $0.1 \% \mathrm{CF}_{3} \mathrm{CO}_{2} \mathrm{H}$ (Agilent, CA, USA/Cheshire, UK). Tested compounds were of at least $97 \%$ peak area purity, using the following columns and conditions: A: Agilent Zorbax Eclipse XDB-C18 $50 \times 4.6 \mathrm{~mm} 1.8$ micron column (Part \#927975-902) maintained at $30^{\circ} \mathrm{C}$. Solvent A water (0.1\% TFA); Solvent B acetonitrile (0.07\% TFA), gradient 5 min 95\% A to 95\% B; 1 min hold; $1 \mathrm{~min}$ recycle; $30 \mathrm{~s}$ hold. UV detection@ 210 and $254 \mathrm{~nm}$ with no reference. B: Agilent Zorbax C8 $150 \times 4.6 \mathrm{~mm}$ 5 micron column maintained at $30^{\circ} \mathrm{C}$. Solvent A water (0.1\% TFA); Solvent B acetonitrile (0.07\% TFA), gradient 10 min $95 \%$ A to $95 \%$ B; 2 min hold; then recycle. UV detection as B.

Preparations of compounds 3-5 and 8-19 were given previously [12,13]; an improved preparation of compound 13 follows. 
<smiles>CC(=O)Oc1ccccc1C(=O)Nc1ncc([N+](=O)[O-])s1</smiles>

1<smiles>O=C(Nc1ncc([N+](=O)[O-])s1)c1ccccc1O</smiles>

2<smiles>CC(=O)Oc1ccccc1C(=O)Nc1ncc(Cl)s1</smiles><smiles>CC(=O)Oc1ccccc1C(=O)Nc1ncc(Br)s1</smiles>

$\mathrm{SO}_{2} \mathrm{Me}$

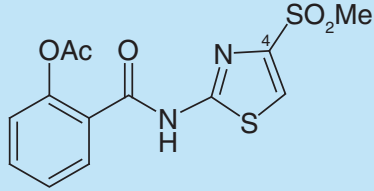

5

Figure 1. Thiazolide structures.

Figure 2. Thiazolide prodrugs.

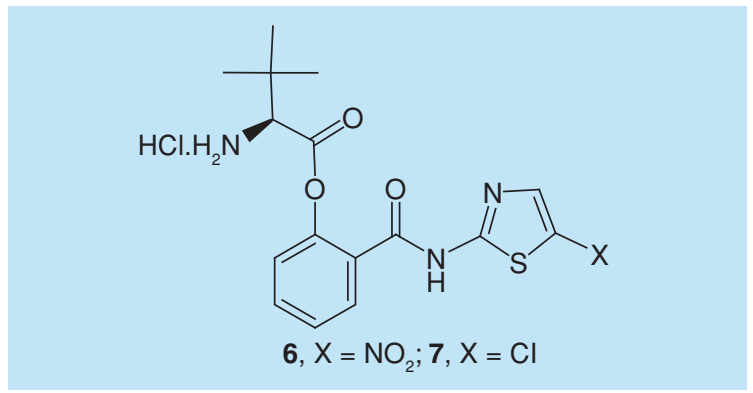

\section{(Ethylthio)-2-bromoacetate (21)}

Following the general procedure of P Rao et al. [15], bromoacetyl bromide 20 (1.67 ml, $3.87 \mathrm{~g}, 19.2 \mathrm{mmol})$ was added in one portion to a stirred suspension of sodium thioethoxide $(1.59 \mathrm{~g}, 18.9 \mathrm{mmol})$ in anhydrous ether $(120 \mathrm{ml})$, initially at $0^{\circ} \mathrm{C}$. The mixture was allowed to regain room temperature and kept under a nitrogen atmosphere for $16 \mathrm{~h}$, then washed with saturated aqueous $\mathrm{NaHCO}_{3}(2 \times 30 \mathrm{ml})$ and evaporated without heating to afford the thioester $(2.99 \mathrm{~g}, 86 \%)$, which was rather unstable and used immediately; ${ }^{1} \mathrm{H}$ NMR 1.30 (3 H, t, $\left.\mathrm{CH}_{3} \mathrm{CH}_{2} \mathrm{~S}\right), 2.98\left(2 \mathrm{H}, \mathrm{q}, \mathrm{CH}_{3} \mathrm{CH}_{2} \mathrm{~S}\right)$ and $4.04\left(2 \mathrm{H}, \mathrm{s}, \mathrm{BrCH}_{2} \mathrm{CO}\right) ;{ }^{13} \mathrm{C} \mathrm{NMR}$ 14.5, 24.6, 33.6 and 192.8.

\section{2-(t-Butoxycarbonyl)amino-4-(ethylthio)thiazole 22}

$N$-(t-butoxycarbonyl)thiourea [16] $(2.90 \mathrm{~g}, 16.5 \mathrm{mmol})$ was added to solution of thioester 21 (2.96 g, $16.2 \mathrm{mmol})$ in isopropanol $(30 \mathrm{ml})$ and stirred at $0^{\circ} \mathrm{C}$, then allowed to regain room temperature. After $16 \mathrm{~h}$, an almost clear pale yellow solution had formed; freshly activated $4 \AA^{\circ}$ molecular sieves $(1 \mathrm{~g})$ were added and stirring continued for another $24 \mathrm{~h}$. A mixture of EtOAc $(50 \mathrm{ml})$ and half satd. aq. $\mathrm{NaHCO}_{3}(50 \mathrm{ml})$ was added, then the mixture was filtered, the aqueous phase was extracted with further EtOAc $(20 \mathrm{ml})$ and the combined organic extracts were washed with water. Evaporation led to a light orange gum which was chromatographed, eluting with a gradient of 10-20\% EtOAc hexane. Appropriate fractions were pooled and evaporated to afford the product as a very pale yellow solid, $2.28 \mathrm{~g} \mathrm{(54 \% );}{ }^{1} \mathrm{H}$ NMR1.30 (3 H, t, $\left.\mathrm{CH}_{3} \mathrm{CH}_{2} \mathrm{~S}\right), 1.56\left(9 \mathrm{H}, \mathrm{s}, \mathrm{Me}_{3} \mathrm{CO}\right), 2.93\left(2 \mathrm{H}, \mathrm{q}, \mathrm{CH}_{3} \mathrm{CH}_{2} \mathrm{~S}\right)$, 6.68 (1 H, s, 5-H) and 8.45 (1 H, br s, NH); ${ }^{13} \mathrm{C}$ NMR 14.7, 27.9, 28.2, 82.9, 109.5, 143.5, 152.0 and 160.0.

\section{2-Amino-4-(ethylthio) thiazole 23}

The protected intermediate $22(0.78 \mathrm{~g}, 3.00 \mathrm{mmol})$ dissolved in $\mathrm{CH}_{2} \mathrm{Cl}_{2}(10 \mathrm{ml})$ was treated with $\mathrm{CF}_{3} \mathrm{CO}_{2} \mathrm{H}$ $(3.0 \mathrm{ml})$ and stirred at $20^{\circ} \mathrm{C}$. Further $\mathrm{CF}_{3} \mathrm{CO}_{2} \mathrm{H}(1.0 \mathrm{ml})$ was added after $3 \mathrm{~h}$; after $4 \mathrm{~h}$, the solution was cooled to $0^{\circ} \mathrm{C}$, stirred and cautiously treated with a solution of $\mathrm{Na}_{2} \mathrm{CO}_{3}(6.5 \mathrm{~g})$ in water $(30 \mathrm{ml})$. The organic phase was separated and two further $\mathrm{CH}_{2} \mathrm{Cl}_{2}$ extracts $(10 \mathrm{ml}$ each) taken, then the combined extracts were dried and evaporated to afford the amine $(0.46 \mathrm{~g}, 96 \%)$ as a light orange oil; ${ }^{1} \mathrm{H}$ NMR $1.30\left(3 \mathrm{H}, \mathrm{t}, \mathrm{CH}_{3} \mathrm{CH}_{2} \mathrm{~S}\right), 2.91(2 \mathrm{H}$, 
q, $\left.\mathrm{CH}_{3} \mathrm{CH}_{2} \mathrm{~S}\right), 5.12\left(2 \mathrm{H}\right.$, br s, $\left.\mathrm{NH}_{2}\right)$ and $6.31(1 \mathrm{H}, \mathrm{s}, 5-\mathrm{H})$. This material darkened rapidly on storage and was reacted as soon as possible.

\section{2-Acetoxybenzoyl-N-[(4-ethylthio)thiazol-2-yl]amide 24}

O-Acetylsalicyloyl chloride $(0.61 \mathrm{~g}, 3.07 \mathrm{mmol})$ was added in one portion to a stirred solution of amine 23 $(0.434 \mathrm{~g}, 2.71 \mathrm{mmol})$ in anhydrous THF $(10 \mathrm{ml})$ at $20^{\circ} \mathrm{C}$. When a clear solution had formed, $N$-ethyl morpholine $(0.375 \mathrm{ml}, 3.00 \mathrm{mmol})$ was added in one portion and stirring continued. After $18 \mathrm{~h}$, further acid chloride $(0.30 \mathrm{~g})$ and $N$-ethyl morpholine $(0.19 \mathrm{ml})$ were added and stirring continued. After 4 days in all, when no amine was visible by thin layer chromatography, the mixture was diluted with EtOAc $(40 \mathrm{ml})$ and washed successively with $2 \mathrm{M}$ $\mathrm{HCl}$, backwashing with a little EtOAc, then with satd. aq. $\mathrm{NaHCO}_{3}$, water and evaporated. The crude product was chromatographed on silica with a gradient of 25-33\% EtOAc hexane; appropriate fractions were pooled and evaporated to afford the product $(0.707 \mathrm{~g}, 81 \%)$ as a very light yellow solid; ${ }^{1} \mathrm{H}$ NMR $1.34\left(3 \mathrm{H}, \mathrm{t}, \mathrm{CH}_{3} \mathrm{CH}_{2} \mathrm{~S}\right)$, $2.45\left(3 \mathrm{H}, \mathrm{s}, \mathrm{CH}_{3} \mathrm{CO}\right), 2.98\left(2 \mathrm{H}, \mathrm{q}, \mathrm{CH}_{3} \mathrm{CH}_{2} \mathrm{~S}\right), 6.77\left(1 \mathrm{H}, \mathrm{s}, 5^{\prime}-\mathrm{H}\right), 7.24(1 \mathrm{H}, \mathrm{d}, \mathrm{ArH}), 7.41(1 \mathrm{H}, \mathrm{t}, \mathrm{ArH})$, $7.61(1 \mathrm{H}, \mathrm{t}, \mathrm{ArH}), 8.04(1 \mathrm{H}, \mathrm{d}, \mathrm{ArH})$ and $9.93(1 \mathrm{H}, \mathrm{br} \mathrm{s}, \mathrm{NH}) ;{ }^{13} \mathrm{C}$ NMR 14.7, 21.2, 27.9, 110.6, 123.7, 124.7, 126.7, 130.9, 133.6, 144.0, 148.4, 157.5, 162.1 and 168.3; found: $\mathrm{m} / \mathrm{z}, 345.0339 ; \mathrm{C}, 52.5 ; \mathrm{H}, 4.4 ; \mathrm{N}$, 8.7; $\mathrm{S}, 1$ 19.6. $\mathrm{C}_{14} \mathrm{H}_{14} \mathrm{~N}_{2} \mathrm{O}_{3} \mathrm{SNa}$ requires $\mathrm{m} / \mathrm{z}, 345.034 ; \mathrm{C}_{14} \mathrm{H}_{14} \mathrm{~N}_{2} \mathrm{O}_{3} \mathrm{~S}$ requires $\mathrm{C}, 52.2 ; \mathrm{H}, 4.4 ; \mathrm{N}, 8.7: \mathrm{S}, 19.9 \%$; HPLC conditions A.

\section{2-Acetoxybenzoyl-N-[(4-ethanesulfonyl)thiazol-2-yl]amide 13}

Meta-chloroperbenzoic acid ( $<77 \%$ spec, $0.98 \mathrm{~g}$ ) was added over $1 \mathrm{~min}$ to a stirred solution of 4-ethylthio compound $24(0.59 \mathrm{~g}, 1.83 \mathrm{mmol})$ in anhydrous $\mathrm{CH}_{2} \mathrm{Cl}_{2}(15 \mathrm{ml})$ at $0^{\circ} \mathrm{C}$. Stirring was continued for $1.5 \mathrm{~h}$ while the mixture was allowed to regain $20^{\circ} \mathrm{C}$, then a mixture of EtOAc $(50 \mathrm{ml})$ and $10 \%$ aq. $\mathrm{Na}_{2} \mathrm{~S}_{2} \mathrm{O}_{3}(50 \mathrm{ml})$ was added. The organic phase was separated, then the aq. phase backwashed with EtOAc $(10 \mathrm{ml})$ and the combined organic extracts were washed with satd. aq. $\mathrm{NaHCO}_{3}(2 \times)$ and evaporated to a solid which was recrystallized from EtOAc hexane to deliver the product $(0.527 \mathrm{~g}, 79 \%) ;{ }^{1} \mathrm{H}$ NMR $1.34\left(3 \mathrm{H}, \mathrm{t}, \mathrm{CH}_{3} \mathrm{CH}_{2} \mathrm{SO}_{2}\right), 2.43(3 \mathrm{H}, \mathrm{s}$, $\left.\mathrm{CH}_{3} \mathrm{CO}\right), 3.29\left(2 \mathrm{H}, \mathrm{q}, \mathrm{CH}_{3} \mathrm{CH}_{2} \mathrm{SO}_{2}\right), 7.27(1 \mathrm{H}, \mathrm{d}, \mathrm{ArH}), 7.42(1 \mathrm{H}, \mathrm{t}, \mathrm{ArH}), 7.64(1 \mathrm{H}, \mathrm{t}, \mathrm{ArH}), 7.90(1 \mathrm{H}$, s, 5-H), $8.02(1 \mathrm{H}, \mathrm{d}, \mathrm{ArH})$ and $10.07(1 \mathrm{H}, \mathrm{br} \mathrm{s}, \mathrm{NH}) ;{ }^{13} \mathrm{C}$ NMR 7.1, 21.3, 48.5, 121.9, 123.9, 124.0, 126.8, 130.8, 134.2, 147.1, 148.6, 159.3, 162.8 and 168.2; found: C, 47.5; H, 4.0; N, 7.9; S, 18.0. $\mathrm{C}_{14} \mathrm{H}_{14} \mathrm{~N}_{2} \mathrm{O}_{5} \mathrm{~S}_{2}$ requires $\mathrm{C}, 47.5 ; \mathrm{H}, 4.0 ; \mathrm{N}, 7.9: \mathrm{S}, 18.1 \%$; HPLC conditions $\mathrm{B}$.

\section{Antiviral assays}

The antiviral activities of the thiazolides against IAV were determined in Madin-Darby canine kidney (MDCK) cells, widely used for influenza infection, as previously described $[2,17]$. Infection was performed with the A/PuertoRico/8/1934(H1N1) (PR8), a prototype strain of the H1N1 subtype of IAV [18]. MDCK cell monolayers were infected with PR8 for $1 \mathrm{~h}$ at $37^{\circ} \mathrm{C}$ at a multiplicity of infection of $5 \mathrm{HAU}$ (hemagglutinating units) $/ 10^{5}$ cells. Following a 1-h adsorption period, the viral inoculum was removed and, after repeated washings with phosphatebuffered saline, cell monolayers were maintained at $37^{\circ} \mathrm{C}$ in RPMI 1640 (LONZA-CAMBREX, Basel, Switzerland) culture medium containing $2 \%$ fetal calf serum. Virus yield was determined at $24 \mathrm{~h}$ post infection by hemagglutinin titration [2]. The seventeen thiazolides (Table 1 below), dissolved in DMSO, were added immediately after the 1-h adsorption period, and kept in the culture medium throughout the experiment. Controls received equal amounts of DMSO vehicle that did not affect cell viability or virus replication. Cell viability, and hence a selectivity index for each compound tested, was evaluated using the 3-(4,5-dimethylthiazol-2-yl)-2,5-diphenyltetrazolium bromide (MTT) to 3-(4,5-dimethylthiazol-2-yl)-2,5-diphenyltetrazolium bromide formazan conversion assay as described previously [19]. The $\mathrm{IC}_{50}$ (50\% inhibitory concentration), $\mathrm{IC}_{90}$ (90\% inhibitory concentration) and $\mathrm{CC}_{50}(50 \%$ cytotoxic concentration) values of the different antiviral compounds were calculated using Prism 5.0 software. Table 1 summarizes the activity of thiazolides of various structural types against PR8.

In our recent publication [20], in addition to the hemagglutinin titration assay, two independent viral titres were used to measure the potency of nitazoxanide; namely a plaque assay and a TCID 50 infectivity assay, using confluent MDCK monolayers in both cases. The A/Puerto Rico/8/1934(H1N1) strain of IAV was used in all cases. For all three assays, the observed $\mathrm{IC}_{50} \mathrm{~s}$ for nitazoxanide lay between 1.3 and $4.1 \mu \mathrm{M}$ with SD in the range of $0-0.2$. Furthermore, the antiviral activity of NTZ was independent of the multiplicity of infection, whether 0.01 or 10 plaque forming units/cell, and the $\mathrm{IC}_{50}$ was reduced when multistep rather than single-step growth conditions 
Table 1. Activities of $4^{\prime}$-and $5^{\prime}$-substituted thiazolides against influenza A virus in Madin-Darby canine kidney cells with selectivity indices.

\begin{tabular}{|c|c|c|c|c|c|c|c|c|c|}
\hline \multirow[t]{2}{*}{ Compound } & \multirow[t]{2}{*}{$\mathbf{R}_{1}$} & \multirow[t]{2}{*}{$\mathbf{R}_{2}$} & \multirow[t]{2}{*}{$\mathbf{R}_{\mathbf{3}}$} & \multirow[t]{2}{*}{$\mathbf{R}_{\mathbf{4}}$} & \multirow[t]{2}{*}{$\mathbf{R}_{5}$} & \multicolumn{4}{|c|}{$\begin{array}{c}\text { Influenza A (PR8) } \\
\text { MDCK cells }{ }^{\dagger}\end{array}$} \\
\hline & & & & & & $I C_{50}^{\ddagger}$ & $I C_{90}$ & $\mathrm{CC}_{50}^{\S}$ & $\mathrm{SI}^{\mathbb{I}}$ \\
\hline 1 & OAC & $\mathrm{H}$ & $\mathrm{H}$ & $\mathrm{NO}_{2}$ & $\mathrm{H}$ & 3.3 & 22.8 & $>163$ & $>49$ \\
\hline 2 & $\mathrm{OH}$ & $\mathrm{H}$ & $\mathrm{H}$ & $\mathrm{NO}_{2}$ & $\mathrm{H}$ & 3.8 & 34 & $>189$ & $>50$ \\
\hline 8 & $\mathrm{H}$ & $\mathrm{H}$ & $\mathrm{OH}$ & $\mathrm{NO}_{2}$ & $\mathrm{H}$ & 0.4 & 3.0 & $>189$ & $>473$ \\
\hline 9 & $\mathrm{OH}$ & $\mathrm{Me}$ & $\mathrm{H}$ & $\mathrm{NO}_{2}$ & $\mathrm{H}$ & 7.2 & 90 & 129 & 18 \\
\hline 3 & OAC & $\mathrm{H}$ & $\mathrm{H}$ & $\mathrm{Cl}$ & $\mathrm{H}$ & 3.4 & 23.6 & 67 & 20 \\
\hline 4 & OAC & $\mathrm{H}$ & $\mathrm{H}$ & $\mathrm{Br}$ & $\mathrm{H}$ & 5.9 & 29.3 & $>147$ & $>25$ \\
\hline 10 & OAC & $\mathrm{Me}$ & $\mathrm{H}$ & $\mathrm{Cl}$ & $\mathrm{H}$ & 12.9 & 29 & 81 & 6.2 \\
\hline 11 & OAC & $\mathrm{H}$ & $\mathrm{H}$ & $\mathrm{H}$ & SMe & 4.9 & $>114$ & $>162$ & $>33$ \\
\hline$( \pm) 12$ & OAC & $\mathrm{H}$ & $\mathrm{H}$ & $\mathrm{H}$ & SOMe & 31 & $>154$ & $>154$ & $>5$ \\
\hline 5 & OAC & $\mathrm{H}$ & $\mathrm{H}$ & $\mathrm{H}$ & $\mathrm{SO}_{2} \mathrm{Me}$ & 0.29 & 2.6 & $>168$ & $>500$ \\
\hline 13 & OAC & $\mathrm{H}$ & $\mathrm{H}$ & $\mathrm{H}$ & $\mathrm{SO}_{2} \mathrm{Et}$ & 0.14 & 7.1 & $>141$ & $>1000$ \\
\hline 14 & $\mathrm{OH}$ & $\mathrm{H}$ & $\mathrm{H}$ & $\mathrm{SO}_{2} \mathrm{Me}$ & $\mathrm{H}$ & 34 & $>168$ & $>168$ & $>5$ \\
\hline 15 & $\mathrm{OH}$ & $\mathrm{H}$ & $\mathrm{H}$ & $\mathrm{CN}$ & $\mathrm{H}$ & 4.1 & 24.5 & $>204$ & $>50$ \\
\hline 16 & $\mathrm{OH}$ & $\mathrm{H}$ & $\mathrm{H}$ & $\mathrm{CO}_{2} \mathrm{Me}$ & $\mathrm{H}$ & 12.6 & 29 & $>180$ & $>14$ \\
\hline 17 & OAC & $\mathrm{H}$ & $\mathrm{H}$ & $\mathrm{CF}_{3}$ & $\mathrm{H}$ & 9.1 & 24.0 & $>152$ & $>16.7$ \\
\hline 18 & OAC & $\mathrm{H}$ & $\mathrm{H}$ & $\mathrm{H}$ & $\mathrm{CF}_{3}$ & 6.1 & 76 & $>152$ & 22.4 \\
\hline 19 & $\mathrm{OH}$ & $\mathrm{H}$ & $\mathrm{H}$ & $\mathrm{H}$ & $\mathrm{H}$ & 18.2 & 91 & $>227$ & $>12.5$ \\
\hline
\end{tabular}

${ }^{\dagger} I C_{50} / I_{90}$ values against IAV, in $\mu$ molar units, were determined in MDCK cells following infection with H1N1 A/PR/8/1934 (PR8) IAV, as described previously [2]

${ }^{\ddagger}$ All antiviral assays were determined at least in duplicate and a standard deviation of $\pm 20 \%$ applies.

$\S$ Cell viability was determined using the MTT formazan dye assay as described previously [19] and used to calculate the $C_{50}$ values, which are also given in $\mu$ molar units.

ISI (selectivity or safety index) = ratio $C C_{50}: I_{50}$.

CC $_{50}$ : 50\% cytotoxic concentration; IAV: Influenza A virus; IC 50 : 50\% inhibitory concentration; IC 90 : 90\% inhibitory concentration; MDCK: Madin-Darby canine kidney; MTT: 3-(4,5dimethylthiazol-2-yl)-2,5-diphenyltetrazolium bromide.

were used. The activities of the leading analogs against other influenza strains, as measured by the alternative assays mentioned, will be disclosed in a future publication.

\section{Quantitative structure-property relationship}

QSAR models were developed for the experimentally measured influenza A activity for the molecules described in the paper in Table 1 . The $\mathrm{IC}_{50}$ values for influenza A (PR8) MDCK cells were converted to pIC 50 values using the transformation $-\log _{10}\left(\mathrm{IC}_{50} \times 10^{-6}\right)$. 3D structures of the ligands were generated using Spartan08 (Wavefunction, CA, USA) [21] and energy minimized using the MMFF94 force field. In total $8250-$, 1- and 2D molecular descriptors/properties were calculated for the set of compounds using DRAGON version 6.0 (TALETE, Milano, Italy) [22]. To reduce redundancy and remove low-information descriptors, descriptors were removed that had an $\mathrm{SD}<0.001$, contained at least one missing value or excluded a descriptor from a pair that had a correlation $\geq 0.95$ [23]. Descriptors were removed that contained the same values for $80 \%$ or more of the training set and the Chorchop procedure was performed to reduce the number of descriptors while retaining the intrinsic information content [24]. The multiple linear regression machine learning method coupled with genetic algorithm subjective descriptor selection (using genalg library and our own scripts in $\mathrm{R}$ [25]) was used to relate the activities (Y) of a set of compounds to their molecular descriptors $(\mathrm{X})$ using a linear equation. The objective fitness function for descriptor selection in this case was chosen to be the adjusted $r^{2}$. Internal validation statistics were calculated using $R$ [25] with libraries boot [26], Data Analysis and Graphics Data and Functions (DAAG [27]) and our own scripts. The QSAR model is reliable as confirmed by various diagnostic plots (Supplementary Figure 1), which indicate that the assumptions on which multiple linear regression is based are true for this dataset. 
<smiles>O=C(Br)CBr</smiles>

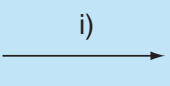

20<smiles>CCSC(=O)CBr</smiles><smiles>NC(=S)N[R6](=O)c1ccccc1</smiles>

21

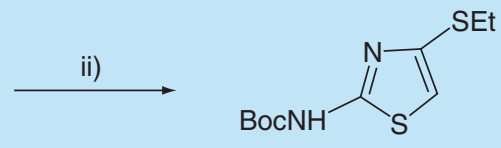

22

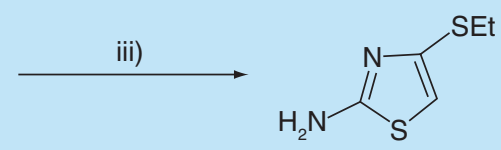

23

iv)

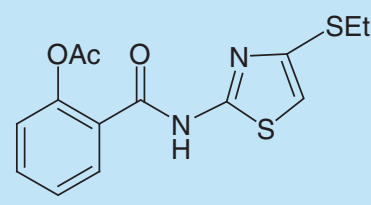

24

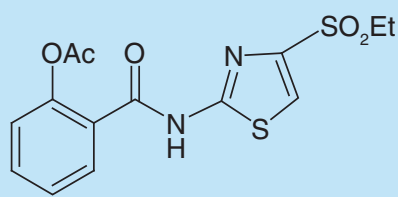

13

Figure 3. Reagents and conditions. (i) NaSEt, $\mathrm{Et}_{2} \mathrm{O}, 20^{\circ} \mathrm{C}, 86 \%$; (ii) equimolar amounts in i-PrOH, $4 \mathrm{~A} \mathrm{MS}^{\circ} 0-20^{\circ} \mathrm{C}$, $48 \mathrm{~h}, 55 \%$; (iii) $\mathrm{CF}_{3} \mathrm{CO}_{2} \mathrm{H}, \mathrm{CH}_{2} \mathrm{Cl}_{2}, 20^{\circ} \mathrm{C}, 96 \%$; (iv) O-acetylsalicyloyl chloride, THF, $\mathrm{N}$-ethyl morpholine, $20^{\circ} \mathrm{C}, 81 \%$; (v) $3-\mathrm{Cl}-\mathrm{C}_{6} \mathrm{H}_{4} \mathrm{CO}_{3} \mathrm{H}, \mathrm{CH}_{2} \mathrm{Cl}_{2}, 90 \%$.

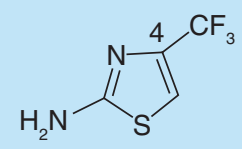

25<smiles>Nc1ncc(C(F)(F)F)s1</smiles>

26
Figure 4. 2-Amino-[4' - and $5^{\prime}$-(trifluoromethyl)] thiazoles.

\section{Results \& discussion}

\section{Chemistry}

The syntheses of the $4^{\prime}$ - and 5'-substituted analogs used in the IAV assays, compounds 3-5 and 8-19 (Table 1), were described in earlier papers $[12,13]$. The $4^{\prime}$-(alkylsulfonyl)thiazolides are particularly active against IAV in this screen, and we now give an improved synthesis, exemplified for compound 13, Figure 3. Reaction of bromoacetyl bromide $\mathbf{2 0}$ with sodium thioethoxide as described by Rao et al. [15] afforded thioester $\mathbf{2 1}$ in very good yield. This intermediate was immediately reacted with $\mathrm{N}$-t-butoxycarbonyl thiourea [16] in 2-propanol at $0-20^{\circ} \mathrm{C}$ over $48 \mathrm{~h}$, affording a good yield of the key intermediate $\mathbf{2 2}$ after chromatography. Addition of powdered $44^{\circ}$ sieves assisted this step by absorbing both water and $\mathrm{HBr}$. Deprotection of $\mathbf{2 2}$ was smoothly achieved with TFA- $\mathrm{CH}_{2} \mathrm{Cl}_{2}, 2: 5$ at $20^{\circ} \mathrm{C}$; the product was found to be unstable in aqueous acid, but the free base $\mathbf{2 3}$ was obtained in excellent yield after prompt neutralization and extraction. It was immediately acylated with $O$-acetylsalicyloyl chloride in THF, and in this series (as opposed to the 2-amino-5-substituted thiazoles) [12,13] the weaker base $\mathrm{N}$-ethylmorpholine was superior to triethylamine, affording the thioether intermediate $\mathbf{2 4}$ in $81 \%$ yield. Finally this compound was oxidized with MCPBA ( 2 equivalents) to afford the desired sulfone 13 in excellent yield.

Earlier [12,13] we prepared the 2-amino-4-(trifluoromethyl)thiazole and 2-amino-5-(trifluoromethyl)thiazole precursors 25 and 26, Figure 4, required for analogs 17 and 18 by multistep routes using sulfone chemistry. One-step preparations are in fact available for both, using respectively a Hantzsch synthesis [28] for $\mathbf{2 5}$ and a radical trifluoromethylation procedure [29] for 26. 


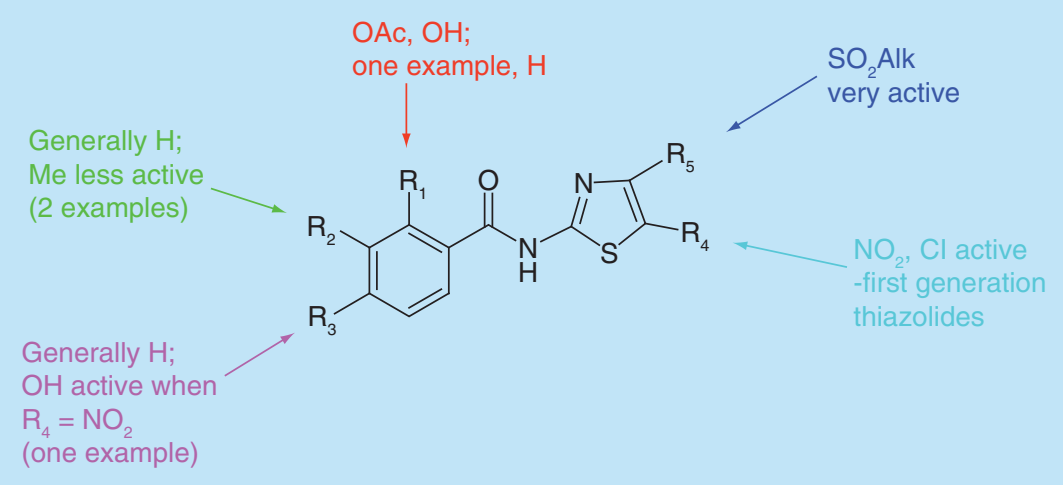

Figure 5. SAR summary.

\section{Antiviral activity}

Antiviral activities (Table 1) are presented as $\mathrm{IC}_{50} / \mathrm{IC}_{90}$ values in micromolar. Considering first $5^{\prime}$-nitro and 5'-halothiazolides, 1-4 and 8-10, there is in general little difference between free phenols and acetates in this screen, typically a factor of two at most, in contrast to the behavior of the thiazolides against hepatitis $\mathrm{C}$ virus [13]. Interestingly, activity is no longer confined to the salicylamides, viz. ortho-hydroxy compounds, for IAV. Thus the para hydroxy isomer 8 [30], not strictly speaking a thiazolide, is about tenfold more active against IAV than nitazoxanide $\mathbf{1}$ itself. The meta-hydroxy isomer, however (not shown) is less active than $\mathbf{1}$ and much less active than $\mathbf{8}$; halo analogs of $\mathbf{8}$ proved inactive. Further evaluation of compound $\mathbf{8}$ is being undertaken.

All the nitro and halo derivatives showed $\mathrm{IC}_{50}$ values in a range of 3.3-12.9 $\mu \mathrm{M}$ : in particular, the very similar activities of nitazoxanide $\mathbf{1}$ and analogs 3 and $\mathbf{4}$ parallel the generally close equivalence of $5^{\prime}-\mathrm{NO}_{2}$ and $5^{\prime}-\mathrm{Br} / \mathrm{Cl}$ seen against the hepatitis viruses $[12,13]$. Introduction of an extra methyl group reduced activity compared with the parent compounds by two- to fourfold (compounds $9, \mathbf{1 0}$ ). Cell safety values were generally acceptable with the exception of compound $\mathbf{1 0 .}$

The 4 '-sulfonyl thiazolides 5 and $\mathbf{1 3}$ expressed outstanding potencies in these assays, with $\mathrm{IC}_{50} \mathrm{~s}<0.3 \mu \mathrm{M}$. The methylthio analog 11 was less potent, and oxidation of the sulfur to provide sulfoxide $( \pm) \mathbf{1 2}$ led to a significant reduction in potency. Further extension or branching of the alkyl chain beyond ethyl, however, led to loss of activity (analogs not illustrated). Regarding other $4^{\prime}$ - and $5^{\prime}$-substituted thiazolides, the $5^{\prime}$-sulfonyl analog $\mathbf{1 4}$ is far less active than its $4^{\prime}$-counterpart. Characteristically, the $5^{\prime}$-nitrile group in $\mathbf{1 5}$ proves a good halogen bioisostere, with similar activity to 3 and $\mathbf{4}$; another strongly electron-withdrawing group, $\mathrm{CO}_{2} \mathrm{Me}$, was less effective as in $\mathbf{1 6}$. Both $5^{\prime}$ - and $4^{\prime}-\mathrm{CF}_{3}$ analogs 17 and $\mathbf{1 8}$ showed fair activity, with the $4^{\prime}$-analog marginally the more active of the pair (contrast the $4^{\prime} / 5^{\prime}$-sulfonyl analogs). The unsubstituted thiazolide 19 [12,31] retained moderate activity. In contrast to their behavior against hepatitis B and C viruses [12,13], a series of salicyloyl anilides, not illustrated, had very little activity in this assay. Finally, the prodrug derivatives $\mathbf{6}$ and $\mathbf{7}$ [14] were equiactive with the parent compounds $\mathbf{1}$ and 3 in this assay. Figure 5 summarizes the SAR data.

\section{Pharmacokinetics of thiazolides \& clinical trials data}

The oral bioavailability of nitazoxanide $\mathbf{1}$ is about $30 \%$ and rises to about $50 \%$ when taken after food [32,33]. Recent data on the $5^{\prime}$-chloro analog 3 have demonstrated a biodisposition at least as good as $\mathbf{1}$ and likely better. Additionally 3 appears to be better tolerated than $\mathbf{1}$; in dogs, no adverse reaction was seen after a dose of up to $2 \mathrm{~g} / \mathrm{kg} /$ day as opposed to a maximum tolerance of $0.12 \mathrm{~g} / \mathrm{kg} /$ day of $\mathbf{1}$. The primary in vivo metabolite of $\mathbf{3}$ observed was the $O$-aryl glucuronide, again in parallel with the behavior of $\mathbf{1}$, and the isolate was identical with a synthetic sample prepared as described earlier [12]. Thus $\mathbf{3}$ has now entered preclinical assessment and full details will be published elsewhere.

The amino-acid ester prodrug 6 [14] showed an absolute bioavailability of $20 \%$ compared with $3 \%$ for the parent tizoxanide; for the chloro analog 7 the corresponding figure was $22 \%$. No serious adverse effects were observed in preclinical toxicology and $\mathbf{6}$ is now being developed for clinical trials, offering the prospect of efficacy at a 
significantly lower dose compared with $\mathbf{1}$. Sulfones $\mathbf{5}$ and $\mathbf{1 3}$ were discovered later and their full evaluation will be described separately.

Nitazoxanide 1 was studied in a major Phase IIB clinical trial enrolling 624 patients presenting viral respiratory infections at 74 centers [3]. Of the total cohort, 257 (41\%) were infected with influenza A or B viruses including $25 \%$ with either H1N1 (17\%) or H3N2 (8\%) strains of IAV. The trial achieved the targeted end point: following administration of $\mathbf{1}(0.6 \mathrm{~g})$ twice daily for 5 days, a statistically significant reduction in time was seen for alleviation of influenza symptoms compared with placebo, $\mathrm{p}=0.008$. A final Phase III study comparing $0.6 \mathrm{~g}$ of $\mathbf{1}$ twice a day to oseltamivir $75 \mathrm{mg}$ twice a day, to the combination of $\mathbf{1}$ and oseltamivir and to a placebo all treatment for 5 consecutive days has been successfully completed in the USA, Australia and New Zealand under an award from the US Department of Health and Human Services to complete the development of $\mathbf{1}$ for treatment of acute uncomplicated influenza [34].

\section{Quantitative structure-property relationship}

No validated drug target information was available so QSAR modeling was employed to relate the experimental inhibition data $\left(\mathrm{IC}_{50}\right)$ with calculated properties of the 17 ligands shown in Table 1 in order to provide a tool that may be used for further compound optimization. In all, 582 molecular properties (descriptors) were calculated [22] and due to the bioactive conformation of the molecules being unknown, these descriptors were independent of conformation. The multiple linear regression model was found using a genetic function algorithm [25] employing adjusted $r^{2}$ as the objective function searching for an optimal four-descriptor model out of the very large number of possible four-descriptor models that exist (four descriptor models were examined in order to minimize chances of an erroneous good correlation [35]). A QSAR model was found that displayed extremely good statistical parameters. For example, the $r^{2}$ value of 0.72 indicates that $72 \%$ of the variance is explained by this model, the $F$ value of 15.8 indicates a high level of significance for the model and all descriptors employed in the model displayed $|\mathrm{t}|$ values greater than two [36]. The model was validated and displayed excellent statistical parameters for leave-one-out cross-validation $r^{2}(0.59)$, threefold-cross-validation $r^{2}(0.58 \pm 0.06)$ and bootstrap $r^{2}(0.72 \pm 0.08)$, averaged over 1000 runs. All of these measures satisfy the proposed parameters for a valid QSAR model [37,38]. In addition, the model identified was shown to satisfy the conditions necessary for a valid linear model [39] (please see Supplementary Information). The final model is depicted graphically (Figure 6) where the excellent correlation between predicted and experimental activity can be clearly seen.

\section{Conclusion}

Summarizing our results (Table 1), out of 17 thiazolides tested, eight had an $\mathrm{IC}_{50}$ of $5.0 \mu \mathrm{M}$ or better against IAV in the cell line employed, with three compounds at $<1.0 \mu \mathrm{M}$ and the nonthiazolide $\mathbf{8}$ was also very active. Cell safety indices were fully satisfactory for all the most active compounds. The best absolute $\mathrm{IC}_{50} \mathrm{~s}$ were obtained for the $4^{\prime}$-sulfonyl analogs, with the ethylsulfonyl analog 13 outstanding at $140 \mathrm{nM}$, and the $5^{\prime}$-chlorothiazolide 3 showing activity equal to nitazoxanide $\mathbf{1}$ itself.

The mode of action of the thiazolides is under ongoing investigation, but there is no evidence that they are acting directly against viral RNA or protein. In the case of influenza A, it has been shown that thiazolides act at a post-translational level after entry into the cell, between the endoplasmic reticulum and the Golgi apparatus, preventing the maturation of the viral hemagglutinin [2]. Intracellular transport and insertion into host plasma membrane are thereby both impaired.

Since thiazolides are selectively acting on hemagglutinin without targeting either M2 ion channels or neuraminidase, it might be expected that they would retain good activity against IAV strains resistant to amantadine or oseltamivir. Indeed, both in vitro and in the clinical trials referred to $[20,34]$ a good synergy between nitazoxanide and oseltamivir is observed, and the lack of direct action against viral RNA or protein should lessen the development of resistance. In support of this, we note that in the case of hepatitis C as well as IAV (PR8 strain) it was shown [40,41] that generation of resistant strains was not observed following challenge with nitazoxanide; indeed susceptibility toward other directly acting antivirals was unaffected. These results are consistent with a cell mediated, not virus mediated, effect of nitazoxanide.

The QSAR results showed a very good correlation, at high significance, between the activities of the thiazolides against IAV and a set of descriptors. Examination of the QSAR model revealed that the descriptors were ZM1Mad (first Zagreb index by Madan vertex degrees), X3Av (average valence connectivity index chi-3), VE1_B(s) (coefficient sum of the last eigenvector from Burden matrix weighted by mass) and F02[N-S] (frequency of N-S topological 


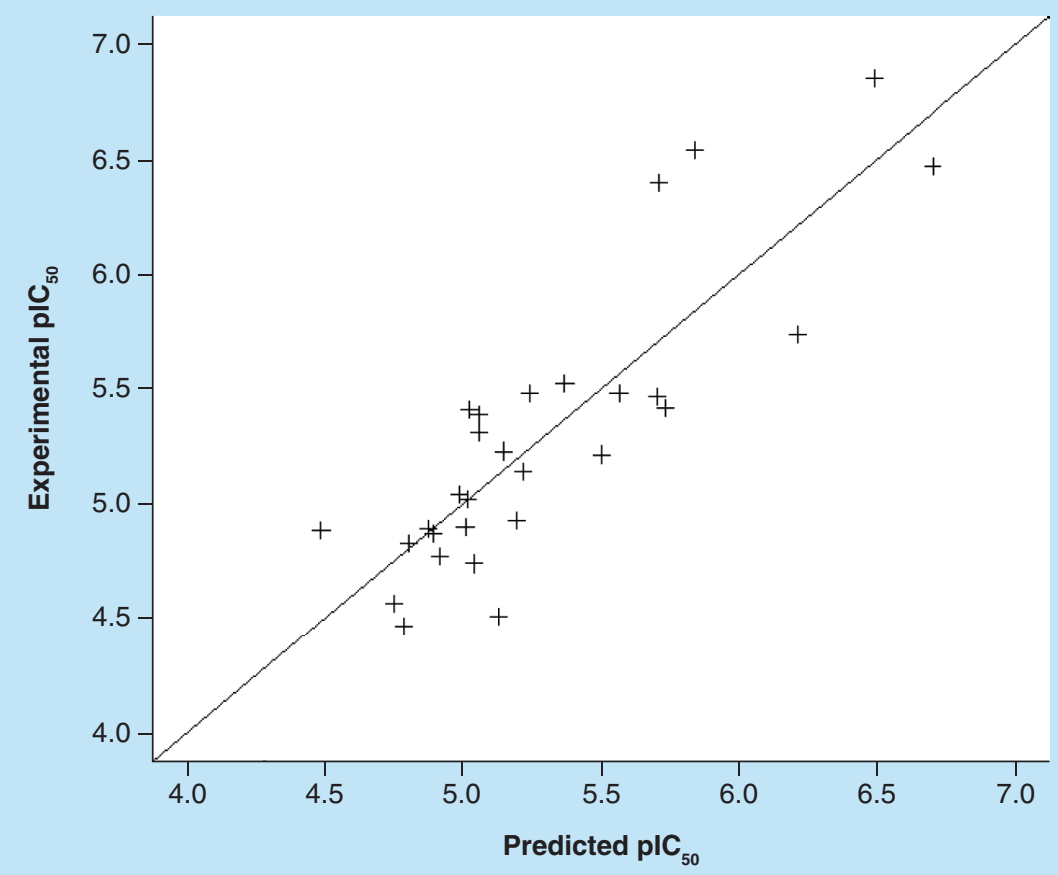

Figure 6. Genetic algorithm-multiple linear regression regression model for influenza A (PR8) Madin-Darby canine kidney cells. Further validation of the statistical significance of this model was obtained through randomization of the activity data and calculation of the $r^{2}$ and threefold cross-validation $r^{2}$ on the permuted data. This process was repeated 1000 -times and the results are plotted in. As can be seen from the histograms of the permuted models for $r^{2}$ and cross-validated $r^{2}$ (Figures 7A \& B), the randomized data do not produce models that perform anywhere near as well as with the true data (indicated by the single vertical lines). Figure $7 C$ displays the model built on the experimental data as a filled green circle, and yet again, none of the permuted models perform as well as the genuine dataset. This series of tests indicates the high significance of the quantitative structure-property relationship model derived from the measured data.

(A)

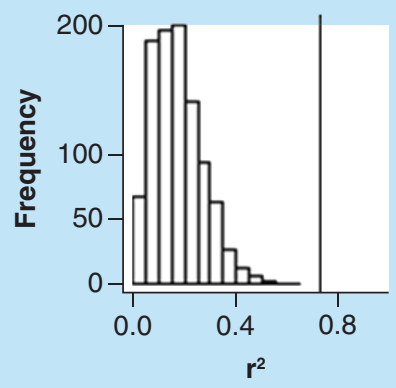

(B)

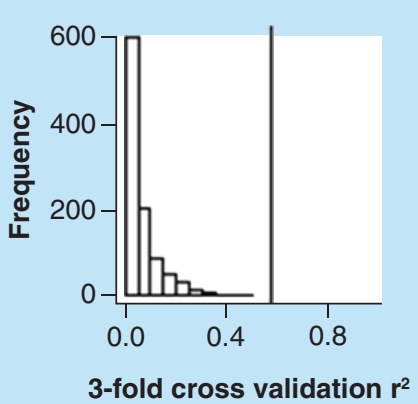

(C)

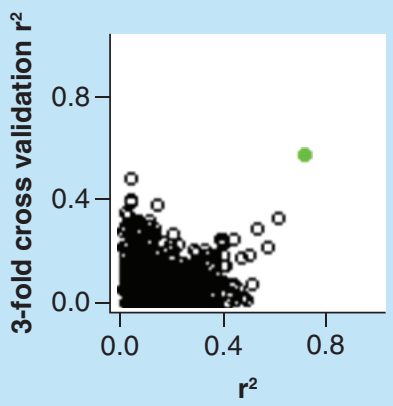

Figure 7. Validation of the regression model. (A) Histogram of $r^{2}$ values from 1000 iterations of randomly permuted influenza A activity values (true data $r^{2}$ shown as solid vertical line at 0.72 ). (B) Histogram of threefold cross-validation $r^{2}$ values from 1000 iterations of randomly permuted influenza A activity values (true data $r^{2}$ shown as solid vertical line at 0.58 ). (C) Plot of $r^{2}$ and threefold cross-validation $r^{2}$ values from 1000 iterations of randomly permuted influenza A activity values as black circles, with the statistical measures from the true data displayed as a solid green circle. 
distance 2). However, precise interpretation of the descriptors for 'manual' molecular design is challenging. Due to the difficulty in readily interpreting the descriptors identified, a correlation was sought with other descriptors that are more readily interpretable. However, no descriptors in the QSAR possessed a correlation with another interpretable descriptor with a correlation $>0.85$. Nevertheless, we have developed a QSAR model, which is statistically robust and may be utilized in the selection and design of future ligands. Virtual screening using this QSAR of an in silico library of candidate compounds will identify potential molecules that will possess potent influenza A activity.

In summary, we have demonstrated that a number of synthetic thiazolides possess good to excellent in vitro activity, with $\mathrm{IC}_{50}$ values in the range $0.14-5.0 \mu \mathrm{M}$, against the replication of a typical strain of H1N1 IAV. In conjunction with recent pharmacokinetic and clinical trial data briefly summarized here, we have thus further exemplified the potential of this class of heterocycles as broad spectrum, well-tolerated antiviral agents. Additionally, by virtue of a clearly observed end effect on viral protein maturation [2], the study of IAV has proved of particular value. Following the successful Phase III clinical trials referred to above, nitazoxanide $\mathbf{1}$ now awaits licensing by the US FDA and the molecules described herein represent excellent starting points for the development of secondgeneration antiviral thiazolides. The impressive activity shown by the new compounds, especially $\mathbf{8}$ and $\mathbf{1 3}$, has clearly identified lead compounds worthy of further evaluation.

\section{Future perspective}

In the future, small molecule therapies will have an important role to play in the control of influenza. We consider especially that, in the case of new flu pandemics, it will be important to have generally effective small molecules to complement immunization programs. Nitazoxanide has already been shown to be effective against IAV both as a single molecule and in conjunction with oseltamivir, and the present paper shows that a number of other thiazolides have valuable activity against IAV, meriting further investigation. Since the thiazolides do not act directly against viral protein or RNA, they are less prone to develop resistance. We conclude that the thiazolides will have an important future role to play in the control of influenza.

\section{Summary points}

Thiazolides as antiviral agents

- Thiazolides, typified by nitazoxanide, are broad-spectrum anti-infective agents.

- Nitazoxanide, under the name Alinia, is a marketed antiparasitic agent notably against Cryptosporidium sp.

- Nitazoxanide is also effective against a range of DNA and RNA viruses, notably rotavirus, hepatitis B and C, with proven clinical efficiency. It has successfully completed Phase III clinical trials against acute uncomplicated influenza.

Structure-activity results

- As well as nitazoxanide, we have now shown a wide range of thiazolides, carrying both $4^{\prime}$ - and $5^{\prime}$-substitution, to possess good activity against an H1N1 strain of influenza A virus (IAV) in MDCK cells.

- In all, eight analogs had an IC 50 of $5.0 \mu \mathrm{M}$ or better against IAV in this assay, providing important new lead compounds.

- The most active was the $4^{\prime}$-ethylsulfonyl analog at $0.14 \mu \mathrm{M}$.

- The SAR of these thiazolides against IAV was different from that seen against hepatitis B or C virus.

Quantitative structure-property relationship study

- A good correlation was seen between the observed activities and those predicted by a range of descriptors.

Mode of action

- The complete mode of action of the thiazolides is under continuing investigation.

- Against influenza A, thiazolides do not act directly against viral protein or RNA but appear to block the final maturation of the virus hemagglutinin.

Supplementary data

See online at: www.future-science.com/doi/full/10.4155/fmc-2017-0217

Financial \& competing interests disclosure

The authors are grateful to Romark Laboratories for funding this work, at the University of Liverpool, UK (2003-2007 and from 2013), the University of Oxford, UK (2009-2011) and at the University of Rome. The authors also thank Mel Schroeder of Kalexsyn, Inc., Kalamazoo, MI, USA for the syntheses of certain compounds. J-F Rossignol is the chairman and chief scientific officer of 
Romark. The authors have no other relevant affiliations or financial involvement with any organization or entity with a financial interest in or financial conflict with the subject matter or materials discussed in the manuscript apart from those disclosed.

No writing assistance was utilized in the production of this manuscript.

\section{Open access}

This work is licensed under the Attribution-NonCommercial-NoDerivatives 4.0 Unported License. To view a copy of this license, visit http://creativecommons.org/licenses/by-nc-nd/4.0/

\section{References}

Papers of special note have been highlighted as: $\bullet$ of interest; $\bullet \bullet$ of considerable interest

1. Rossignol JF, Cavier R. 2-Benzamido nitrothiazoles. Chem. Abs. 83, 28216n (1975).

2. Rossignol JF, La Frazia S, Chiappa L, Ciucci A, Santoro MG. Thiazolides, a new class of anti-influenza molecules targeting viral haemagglutinin at the post-translational level. J. Biol. Chem. 284(43), 29798-29808 (2009).

-. The first disclosure of the efficacy of nitazoxanide as an antiviral agent, and one key aspect of its mode of action.

3. Haffizulla J, Hartman A, Hoppers $M$ et al. Effect of nitazoxanide in adults and adolescents with acute uncomplicated influenza: a double-blind, randomized, placebo-controlled, Phase IIb/III trial. Lancet Infect. Dis. 14(7), 609-618 (2014).

4. Fox LM, Saravolatz LD. Nitazoxanide: a new thiazolide antiparasitic agent. Clin. Infect. Dis. 40(8), 1173-1180 (2005).

5. Korba BE, Montero AB, Farrar K et al. Nitazoxanide, tizoxanide and other thiazolides are potent inhibitors of hepatitis B virus and hepatitis C virus replication. Antivir. Res. 77(1), 56-63 (2008).

6. La Frazia S, Ciucci A, Arnoldi F et al. Thiazolides, a new class of antiviral agents effective against rotavirus infection, target viral morphogenesis, inhibiting viroplasm formation. J. Virol. 87(20), 11096-11106 (2013).

7. Rossignol JF, Abou Zekry M, Abeer Hussein, Santoro MG. Effect of nitazoxanide in treating severe rotavirus diarrhea: a randomized, double-blind, placebo-controlled trial. Lancet 368(9530), 124-129 (2006).

- The first description of the efficacy of nitazoxanide as an antiviral agent in vivo.

8. Rossignol JF, Elfert A, El-Gohary Y, Keeffe EB. Improved virologic response in chronic hepatitis C genotype 4 treated with nitazoxanide, peginterferon and ribavirin. Gastroenterology 136(3), 856-862 (2009).

9. Rossignol JF, Elfert A, Keeffe EB, Treatment of chronic hepatitis C using a 4-week lead-in with nitazoxanide before peginterferon plus nitazoxanide. J. Clin. Gastroenterol. 44(7), 504-509 (2010).

10. Rossignol JF. Thiazolides: a new class of antiviral drugs. Expert Opin. Drug Metab. Toxicol. 5(6), 667-674 (2009).

11. Rossignol JF. Nitazoxanide: a first-in-class broad-spectrum antiviral agent. Antiviral Res. 110, 94-103 (2014).

12. Stachulski AV, Pidathala C, Row EA et al. Thiazolides as novel antiviral agents: 1. Inhibition of hepatitis B virus replication. J. Med. Chem. 54(12), 4119-4132 (2011).

13. Stachulski AV, Pidathala C, Row EA et al. Thiazolides as novel antiviral agents: 2. Inhibition of hepatitis C virus replication. J. Med. Chem. 54(24), 8670-8680 (2011).

14. Stachulski AV, Swift K, Cooper M, Reynolds S, Slonecker SD, Rossignol JF. Synthesis and pre-clinical studies of new amino-acid ester thiazolide prodrugs. Eur. J. Med. Chem. 126, 154-159 (2017).

- Description of a prodrug of nitazoxanide, which greatly improves its bioavailability.

15. Praveen Rao PN, Amini M, Li H, Habeeb AG, Knaus EE. Design, synthesis, and biological evaluation of 6-substituted-3-(4-methanesulfonylphenyl)-4-phenylpyran-2-ones: a novel class of diarylheterocyclic selective cyclooxygenase-2 inhibitors. J. Med. Chem. 46(23), 4872-4882 (2003).

16. Schiavi B, Ahond A, Poupat C, Potier P. Preparation of N-tert-butoxycarbonylthiourea opens the way to protected 2-aminothiazoles. Synth. Commun. 32(11), 1671-1674 (2002).

- The compound is now commercially available.

17. Matlin KS, Reggio H, Helenius A, Simons K. Infectious entry pathway of influenza virus in a canine kidney cell line. J. Cell Biol. 91(3), 601-613 (1981).

- A widely accepted cell line for in vitro anti-influenza assays and is used here.

18. Moran T, Liu YNC, Schulman JL, Bona CA. Shared idiotopes among monoclonal antibodies specific for A/ PR/ 8/ 34 (H1N1) and X-31 (H3N2) influenza viruses. Proc. Natl Acad. Sci. USA 81(6), 1809-1812 (1984).

19. La Frazia S, Amici C, Santoro MG. Antiviral activity of proteasome inhibitors in herpes simplex virus-1 infection: role of nuclear factor-kB. Antivir. Ther. 11(8), 995-1004 (2006).

20. Belardo G, Cenciarelli O, La Frazia S, Rossignol JF, Santoro MG. Synergistic effect of nitazoxanide with neuraminidase inhibitors against influenza A viruses in vitro. Antimicrob. Agents Chemother. 59(2), 1061-1069 (2015).

21. Wavefunction, Inc. Molecular modeling software. www.wavefun.com/ 
22. Talete srl, DRAGON (Software for Molecular Descriptor Calculation) version 6.0 - 2010 - Todeschini R, Consonni V. Molecular descriptors, Wiley-VCH (2009). www.talete.mi.it/

23. PHAKISO - pharmacokinetics in silico. www.phakiso.com/

24. Livingstone DJ, Rahr E. Corchop-an interactive routine for the dimension reduction of large QSAR data sets. Quant. Struct. Act. Relat. 8(2), 103-108 (1989).

25. R Development Core Team. R: a language and environment for statistical computing, R Foundation for Statistical Computing. ISBN, Vienna, Austria 3-900051-07-0 (2011). www.R-project.org/

26. Bootstrap functions, functions and datasets for bootstrapping. http://cran.r-project.org/web/packages/boot/index.html

27. DAAG: data analysis and graphics data and functions. http://cran.r-project.org/web/packages/DAAG/index.html

28. Tanaka K, Nomura K, Oda HI, Yoshida S, Mitsuhashi K. Synthesis of trifluoromethylthiazoles and their application to azo dyes. J. Heterocyclic Chem. 28(4), 907-911 (1991).

29. Qi Q, Shen Q, Lu L. Polyfluoroalkylation of 2-aminothiazoles. J. Fluorine Chem. 133(SI), 115-119 (2012).

30. Dymicky M, Huhtanen CN, Wasserman AE. Inhibition of clostridium botulinum by 5-nitrothiazoles. Antimicrob. Agents Chemother. 12(3), 353-356 (1977).

31. Luo QL, Li JY, Liu ZY et al. Inhibitors of type I MetAPs containing pyridine-2-carboxylic acid thiazol-2-ylamide. Part 1: SAR studies on the determination of the key scaffold. Bioorg. Med. Chem. Lett. 15(3), 635-638 (2005).

32. Stockis A, De Bruyn S, Gengler C, Rosillon D. Nitazoxanide pharmacokinetics and tolerability in man during 7 days dosing with 0.5 and 1 g b.i.d. Int. J. Clin. Pharmacol. Ther. 40(5), 221-227 (2002).

33. Broekhuysen J, Stockis A, Lins RL, De Graeve J, Rossignol JF. Nitazoxanide: pharmacokinetics and metabolism in man. Int. J. Clin. Pharmacol. Ther. 38(8), 387-394 (2000).

34. Clinical trials database: NCT01610245. https://clinicaltrials.gov/ct2/show/NCT01610245

35. Topliss JG, Edwards RP. Chance factors in studies of quantitative structure-activity relationships. J. Med. Chem. 22(10), 1238-1244 (1979).

36. Tropsha A, Gramatica P, Gombar VK. The importance of being earnest: validation is the absolute essential for successful application and interpretation of QSPR models. QSAR \& Combin. Sci. 22(1), 69-77 (2003).

37. Eriksson L, Jaworska J, Worth AP, Cronin MT, McDowell RM, Gramatica P. Methods for reliability and uncertainty assessment and for applicability evaluations of classification- and regression-based QSARs. Environ. Health Perspect. 111(10), 1361-1375 (2003).

38. Podlogar BL, Muegge I, Brice LJ, Computational methods to estimate drug development partners. Curr. Opin. Drug Discov. Devel. 4(1), $102(2001)$.

39. Scior T, Medina-Franco JL, Do QT, Martinez-Mayorga K, Yunes Rojas JA, Bernard P. How to recognize and workaround pitfalls in QSAR studies: a critical review. Curr. Med. Chem. 16(32), 4297-4313 (2009).

- An important overview on avoiding hazards in developing quantitative structure-property relationship study models.

40. Belardo G, La Frazia S, Carta S, Rossignol JF, Santoro MG. Nitazoxanide, a novel potential anti-influenza drug, acting in synergism with neuraminidase inhibitors. Presented at: Infectious Diseases Society of America, 49th Annual Meeting ,Boston, MA, USA, 20-23 October 2011.

41. Korba BE, Elazar M, Lui P, Rossignol JF, Glenn JS. Potential for hepatitis C resistance to nitazoxanide or tizoxanide. Antimicrob. Agents Chemother. 52(11), 4069-4071 (2008). 